\title{
Model of Development Rural Tourism Batik in Banyuwangi: A sustainable Development Approach
}

\author{
Nur Anita Yunikawati1, ${ }^{1,}, N^{\prime}$ 'matul Istiqomah ${ }^{1}$, Marzanah A Jabbar ${ }^{2}$, and Fatimah Sidi ${ }^{2}$ \\ ${ }^{1}$ Universitas Negeri Malang, Jl. Semarang No.5, Sumbersari, Kec. Lowokwaru, Kota Malang, 65145 \\ Jawa Timur, Indonesia \\ ${ }^{2}$ Universiti Putra Malaysia, JALAN UNIVERSITI 1 Serdang, 43400 Seri Kembangan, Selangor, \\ Malaysia
}

\begin{abstract}
The role of the national tourism sector is increasingly important in line with the development and contribution of the tourism sector through foreign exchange, income, regional development as well as investment and employment and business development in various parts of Indonesia. Tourism villages have become a trend of developing alternative villages in the last decade. From year to year, the number of tourist villages in Indonesia has also grown rapidly. East Java Province is one of the provinces that has consistently developed the Tourism Village. Banyuwangi Regency has many interesting tourism objects to develop, such as nature tourism, historical tourism, art and cultural tourism or other tourism. Tampo Village is famous for its batik village tours which provide typical Banyuwangi batik. This study uses a research and development (R\&D) design. The expected outputs are in the form of analysis of information updates on the potential of the batik tourism village and the batik tourism village development model. The development of the batik industry in Tampo aims to preserve cultural wealth and develop the potential that exists in Tampo Village. The potential for batik is one of the means to increase the economic growth of the village of Tampo. Through the development of a tourism village using the CBT approach, it is hoped that the Tampo batik tourism village can become one of the tourist attractions in Banyuwangi Regency.
\end{abstract}

\section{Introduction}

Nowadays tourism provides a high contribution to a country's GDP[1][2][3]. The role of the national tourism sector is increasingly important in line with the development and contribution of the tourism sector through foreign exchange, income, regional development as well as investment and employment and business development in various parts of Indonesia. Based on data from the Ministry of Tourism and Creative Economy, [4] tourism's contribution to Indonesia's GDP in 2019 is $4.80 \%$. This value increased 0.30 points compared to last year. In addition, data from the Ministry of Tourism and Creative

* Corresponding author: nur.anita.fe@um.ac.id 
Economy shows that in the last 5 (five) years (2015-2019) the average number of tourists visiting various regions in Indonesia has reached 13.5 million tourists per year. July-August is the peak in which foreign tourists visiting Indonesia averages 1.29 million tourists per month, while January-February is the month with the least number of visits, namely the average tourist visiting reaches 984 thousand tourists. per month. This indicates that the tourist attraction of Indonesia in the eyes of the world is very high because it is supported by enchanting natural conditions such as mountains, beaches, underwater scenery and also Indonesian culture.

Since 2017 there has been a shift in tourism demand from mass tourism to alternative tourism or commonly referred to as thematic tourism[5][6] namely tours that prioritize natural tourism [7], culture or local characteristics that exist in an area [8]. This shift in tourism trends is an opportunity for each region that has certain characteristics to develop tourism with a certain theme, for example tour packages that prioritize culture, nature, and something unique from certain areas that encourage participation of local communities as actors. One of them is the formation of a tourist village.

Tourism villages have become a trend of developing alternative villages in the last decade. From year to year, the number of tourist villages in Indonesia has also grown rapidly. Until the end of 2018, the Central Statistics Agency (BPS[9] recorded 1,734 tourist villages out of a total of 83,931 villages in Indonesia. The number of tourist villages is spread across 7 islands in Indonesia, namely the ones with the most tourist villages are Java and Bali which have 857 tourist villages, followed by Sumatra Island as many as 355 Tourism Villages, ranking when occupied by Nusa Tenggara as much. 189 Tourism Villages, then Sulawesi Island has 119 Tourism Villages, Kalimantan Island 117 Tourism Villages, Papua 74 Tourism Villages and 23 Tourism Villages on Maluku Island. A tourist village is an alternative tourism that utilizes the resources and traditions of the local community. One way to develop a tourist village is by utilizing local commodity-based resources. This is to support the development of a tourist village as a center for economic, social and cultural activities.

East Java Province is one of the provinces that has consistently developed Tourism Villages in all areas of the province of East Java. In 2018 the number of tourist villages in East Java was 54 Tourism Villages. Through the East Java Tourism Office, the East Java Province Tourism Village Association (ASIDEWI) has formed to accommodate and serve as a forum for empowering all tourism village managers in East Java. One of the districts in East Java Province, namely Banyuwangi Regency, Banyuwangi Regency as one of the ODTW (tourist attraction objects) in East Java has stipulated in the 2016-2021 RPJM and 2010-2025 RPJP as the basis for the development of Banyuwangi Regency regarding the direction of tourism development policies, namely : increasing the income of community members through tourism, developing the tourism sector as a source of regional income, increasing the ability of community members to be able to get great benefits for tourism activities, creating a tourism awareness society through sapta charm, so as to create an atmosphere that supports and supports the growing development tourism business and activities.

As one of the tourist destinations in East Java, Banyuwangi Regency has many interesting tourism objects to be developed, such as natural tourism, historical tourism, art and cultural tourism or other tourism. However, there is one different tourist spot when tourists visit Tampo Village, Cluring District, Banyuwangi Regency. Tampo Village is famous for its batik village tours which provide typical Banyuwangi batik. In this village, there are many batik craftsmen who are the main attraction of this tourist spot. The batik products from the Tampo Village are a supplier of batik throughout the Banyuwangi Regency. At the initiative of the Banyuwangi Regent, all employees and students, both elementary and high schools, are obliged to wear elephant motif oling batik every 
Thursday. The elephant oling motif is a typical motif of Banyuwangi batik. This is used for the promotion of Banyuwangi batik and also as a means of encouraging the community to preserve the culture of wearing batik. Based on the policy of the Banyuwangi Regent, Tampo Village as a batik producing village is never empty of orders, both orders from agencies and communities or individuals. So that the village government of Tampo tries to make Tampo Village a Banyuwangi Batik Village by embracing craftsmen who are in Tampo Village to work together to make the tampo batik center a center of excellence in Tampo Village and can be recognized by the wider community. The existence of a batik association is one of the main things to be promoted in this village, but in Tampo Village not all batik makers are members of the batik community, this is because the community's benefits have not been maximized for the craftsmen. In addition, there is no standard price for batik sales, there is no fierce competition so that the craftsmen are reluctant to innovate. Based on this background, the purpose of the research is to formulate a sustainable economic development model for Community-Based Tourism in Kampung Batik as a tourist destination, and to provide recommendations that can be formulated for economic sustainability in Kampung Batik.

\section{Method}

This study uses a research and development (R\&D) design. The expected outputs are in the form of analysis of information updates on the potential of the batik tourism village and the batik tourism village development model. The location of this research is located in Tampo Village, Cluring District, Banyuwangi Regency, East Java Province, Indonesia. The sample selection of the research area in the village of Tampo was carried out purposively. As for the consideration in determining the research area is a geographic and spatial approach so that it is expected to reveal about the development of the batik tourism village in Tampo Village.

The data collected to support this research are primary data and secondary data. Data collection techniques include literature study, observation, interviews, and Focus Group Discussion (FGD). Literature study is carried out through reference books, magazines, national and international journals, and the internet. Observations are made through exploration and observation in the research area. Interviews were conducted using research instruments. The FGD was conducted to determine and estimate business opportunities for batik commodities that already exist and will be developed to become the center for the batik commodity industry, and subsequently used as superior commodities and become bargaining points in determining the development model for batik tourism villages.

The data analysis of this research was carried out descriptively. Descriptive analysis was conducted to further explain matters related to the research phenomenon. Data validity techniques used triangulation of sources, methods and theories. The data analysis technique used is an interactive model. The research subjects consisted of batik craftsmen, village heads and community leaders in Tampo Village, Cluring District, Banyuwangi Regency.

\section{Result and Discussion}

\subsection{Potential of Banyuwangi Batik}

Banyuwangi Regency has the potential for a potential batik industry. In the development of the batik industry, several cluster areas have been formed, including: Kabat, Cluring, Banyuwangi, Sempu and Kalipuro districts. Some areas that become the object of research are in Kabat District, namely Pakistaji Village, Cluring District, Tampo Village and 
Banyuwangi District in Temenggungan Village. Banyuwangi Batik is a manifestation of the aesthetic value of Banyuwangi's distinctive decorations. Banyuwangi Batik motifs are not only an aesthetic manifestation of the variety of decorations but also have values shared by the Banyuwangi community. All the names of the original batik motifs of Banyuwangi Regency are influenced by natural conditions. To date, around 21 types of Banyuwangi original batik motifs have been recognized nationally. Some of the Banyuwangi Batik motifs are Gajah Oling, Kangkung Setingkes, Alas Kobong, Paras Gempal, Broken Coffee, Sembruk Cacing, Gedegan, Ukel, Blarak Semplah, Moto Pitik, and so on. Batik Gajah Oling or Gajah Uling motif, the motif is in the form of animals such as eels which are quite large in size. The Gajah Oling motif, which is believed to be the original motif of Banyuwangi Batik, symbolizes a power that grows from within the Banyuwangi community. The meaning of the Gajah Oling motif is related to the religious character of the Banyuwangi community with the mention of "Eling Elephant" which has the meaning that the elephant is a large animal, means enormous, while uling means eling (remember), as a whole it can be interpreted that Batik Gajah Oling invites to always remember God is the basis of the life journey of the Banyuwangi people. There are also those who say that the snake elephant is curved like an elephant's trunk. This characteristic of batik is shaped like a question mark, which is philosophically the form of an elephant's trunk and a snakehead at the same time. Apart from the main elements, the batik character is also surrounded by a number of other attributes. Among them, butterflies, suluran (a kind of sea plant), and manggar (areca flower or coconut flower). Currently the Gajah Oling motif is being developed in such a way as to follow market tastes. The Sembruk Cacing motif also has motifs such as worms and Gedegan motifs also like gedeg (woven bamboo). The existing batik motifs are a reflection of the natural wealth that exists in Banyuwangi. Batik motifs such as in Banyuwangi will not be found in other areas and are typical of Banyuwangi.

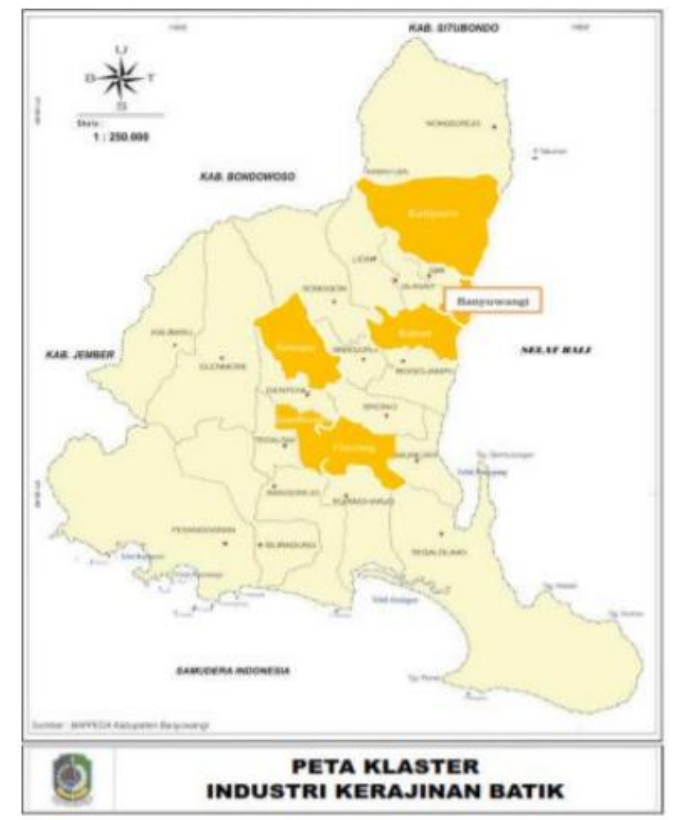

Fig. 1. Cluster of Batik Industry

Banyuwangi City has several batik centers, namely Sayu Wiwit, Tirta Wangi, Sritanjung, and Srikandi which are located in Banyuwangi sub-district, Virdes Batik in 
Cluring District. Each batik center has its own characteristics, the most striking of which are Sayuwiwit and Virdes batik studios. Sayuwiwit still maintains conventional Banyuwangi batik motifs, based on the old standard of only playing colors and blending patterns, while Virdes develops Banyuwangi Batik, combining standards and consumer demands.

\subsection{Tampo Village as a Batik Tourism Village}

Tampo Village is located in one of the sub-districts in Banyuwangi Regency, namely Cluring District. This design has an area of $5.22 \mathrm{~km}^{2}$. The population in this village is approximately 7,076 people. This village is famous for its batik centers in Banyuwangi Regency. There are 17 batik craftsmen in this village [10] which spans one block in Tampo Village. The existence of a batik industry cluster in Tampo Village makes it easier for visitors to buy batik. Through the encouragement of the village government, Tampo Village declared itself a Batik Tourism Village. There is a gate as a guide as a batik tourism village. In addition, in order to regenerate the batik, it is stated in the Canting Sewu Festival which is held along the axis road of Simbar Hamlet, Tampo Village. The Canting Sewu Festival is a series of Banyuwangi Batik Festival (BBF) events dedicated to promoting various batik products in Banyuwangi, as well as linking local batik makers with the national batik industry. This festival is an event to promote the existence of a batik tourism village. The festival which takes place for one week every November every year is always crowded with tourists.

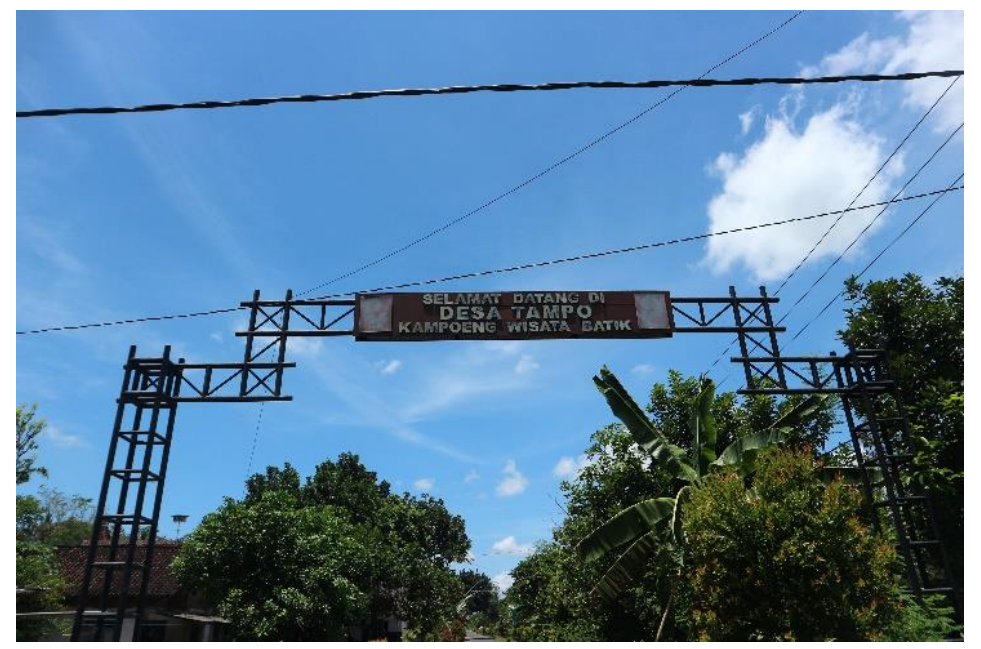

Fig 2. Tampo Village

The development of tourism, both mass and thematic tourism, should be based on conditions and carrying capacity with the aim of creating long-term mutually beneficial interactions between the achievement of tourism development goals, increasing the welfare of local communities, and sustainable environmental carrying capacity in the future[11]. This is done by developing attractiveness, accessibility and facilities that support recreation, tourists and local residents mutually beneficial.

a. Attraction

Objects and tourist attractions are the main assets that must be owned by a tourism development area[12][13][14]. In general, Tampo Village has its own power compared to other areas in Banyuwangi, where the batik craftsmen are gathered together along the same road. They set up a batik production workshop center, and a showroom to display their 
batik handicrafts. The showroom function is not only for displaying batik but also for promotion

\section{b. Accessibility}

Accessibility plays an important role in tourism development in an area[15]. Tampo Village is located in Cluring District, based on data from the Central Statistics Agency (BPS) [10] in the north it is directly adjacent to Srono District, the south is directly adjacent to Purwoharjo District, the west is directly bordered by Gambiran District, and in the east it is directly adjacent to Muncar District . Based on this geographical location, Cluring District has its own advantages because several Districts directly adjacent to Cluring District are densely populated areas and are visited by many tourists. So that this can be an attractive factor for tourist visits to Cluring District, to be precise, Tampo Village.

When viewed from the means of transportation to this village are still lacking. This can be seen from the absence of regular public transportation facilities. The distance from the sub-district capital is not too far, ranging from $3 \mathrm{~km}$, but public transportation facilities are not yet available, so the travel time to this village is still difficult to reach. In addition, road access that is not yet supportive (there are several damaged and narrow roads) is an obstacle to getting to the tourist village. In addition, there are no signs or road directions to the tourist village. This situation makes it difficult for tourists who will visit tourist sites. The only signs available are in the form of a gate to enter the batik craftsman road, and not placed at the entrance to the batik tourism village.

\section{c. Public facilities and tourism facilities}

The process of developing a tourism village is inseparable from the process of developing tourism support facilities such as transportation, accommodation in the form of homestays or lodging in the form of hotels, public service facilities, arts and so on, must be developed in line with the development of a tourist village [16][17]. This is a basic need because tourism village activities can run well if supported by the availability of supporting facilities that allow tourists to stay and communicate with the community as well as learn the culture and local wisdom of local residents.

The existing facilities, both supporting facilities for getting to tourist sites and tourist sites, are still simple. According to the explanation, one of the Tampo Village officials explained that the tourist location facilities would still be planned and developed. The development plan is included in the long-term village plan which contains long-term plans for the sustainability of the batik tourism village. Included in this plan is the procurement of a culinary industry in the form of restaurants, procurement of homestays, procurement of special places to display batik handicrafts. The provision of this facility has not yet been realized because it is still constrained by local government regulations to determine Tampo Village as a batik tourism village in Banyuwangi. However, all of these facilities have been included in the tourism village development planning.

d. Community Empowerment

An important element in developing a tourism village is community involvement [18][19][20]. This is because the development of a tourist village implies that the participation of the village community is very necessary to establish a joint strategy in order to achieve a common goal, namely the development of a tourist village which will ultimately improve their economic standard of living. In addition, tourism activities encourage new economic activities by utilizing existing natural and human resources. The main involvement by the community in supporting tourist villages can be in the form of providing tourism services and services. This community involvement is commonly referred to as community based tourism. According to the ASEAN Community Base Tourism Standard [21] that Community Based Tourism (CBT) is a form of tourism that involves community empowerment in tourism management and achieving community goals, namely for community welfare to support sustainable development which consists of 
three aspects, namely economic, social, and the environment. So that CBT does not only involve tourism business partnerships and the community to provide benefits for both parties, but also involves community support and also external parties for the development of tourist villages, which will later commit to each other and provide support to communities that can improve mutual welfare.

The establishment of a batik tourism village as a first step in efforts to raise the economic strength of the community. However, the process of developing human resources and increasing the quality of batik production has not been carried out optimally. This can also be seen in the improvement of production quality and continuity, financial efficiency, business network development, and marketing that have not yet been implemented. The success of Tampo Village as a tourist village cannot be separated from the participation of the community. In this case the community with self-awareness manages and develops this village so that it can develop. With the spirit of togetherness, all communities are involved in village development.

\section{e. Marketing and Promotion}

Activities are intensive activities in an effort to strengthen the attractiveness of tourism products to potential tourists. Currently, the implementation of promotions is still carried out independently by each of them through their own social media. In terms of promotion, the village government and craftsmen should work together to create a product window that will attract tourists to visit Tampo Village.

\subsection{Batik Tourism Village Development Model}

In the book "Handbook on Community Based Tourism: How to Develop CBT Sustain"[22] explains that in developing tourism villages, Community Based Tourism (CBT) must play an active role in the development of tourism villages. Therefore, there are 9 steps to develop a tourist village with the CBT approach. The first step is Access Community Needs and Readliness for Tourism. In the first step of the emergence of tourism, the community will enter a different environment, which is likely to change the way of life and their perspective related to the community. This will encourage local people to determine a positive perspective and have the hope that the presence of a tourist village can improve their standard of living. This point of view was tested when at the beginning of the implementation of the tourism village it was not as expected due to various factors, one of which was in terms of marketing that was not optimal. Therefore, communication between tourism actors is very important in this case between batik craftsmen, village government, and tourism village initiators.

The second step is Educate and Prepare the Community for Tourism. In fact, the local community must be well informed and thoroughly educated about various aspects of tourism before the construction of any form of tourism development or activity. The education process must take longer because relatively rural communities have low levels of education. This education and training can be started by conducting several workshops. In the first workshop, the initiator had to invite all residents who were directly involved in the formation of a tourist village. The workshop contains the identification of resources and activities in the village that can attract tourists. In Tampo Village, an interesting activity is the batik activity typical of Banyuwangi. However, it is hoped that the first workshop activity all invitees can give their opinion on things that can attract tourists. After the identification process runs smoothly, the next process is the division of labor. For example, in the village of Tampo, he established the Tourism Awareness Group (POKDARWIS) organization as a forum for youth to develop tourism. Through this POKDARWIS some can be trained as tour guides, some focus on homestay procurement, and so on. In addition, a comparative study to other tourist villages is also an alternative for local residents to 
learn. This is used so that tourism business actors to be formed get direct experience from other regional tourism actors.

The third step is Identify and Establish Leadership / Local Champion. The success of the CBT project cannot be separated from the role of leadership and organization. In this case the government acts as the project initiator, however the sustainability of the CBT program depends on the sense of belonging and support of the local community. So the presence of a leader who has a love for the region is very influential on the long-term sustainability of the tourist village. The village government of Tampo has been the initiator of the batik tourism village, but it needs follow-up support from the local community and a leader who represents the community who has commitment, dedication and enthusiasm to work as a leader.

The fourth step is the Prepare and Develop Community Organization. At this stage the local leader must try to form a community organization as a forum for planning, operating and promoting the CBT project. The involvement of all elements of society here is very important for the smooth running of the CBT project. Youth and women must be involved in this activity, providing training to them will get added value for the tourism village to be established. For example, local youth are suitable for roles as guides and cultural actors. Meanwhile, local women are often entrusted with handling culinary and batik crafts.

The fifth step is the Develop Partnership. Along with the development of the CBT project, the tourist village needs to expand its market segmentation. To increase competitiveness, it is done by forming partnerships with stakeholders. This is common with the development of pentahelix, namely partnerships and collaborations with the government as policy makers, collaboration with universities by applying research results to the community, collaboration with non-governmental organizations (NGOs) to help sustainable tourism and conservation, and development of social media for promotion.

The sixth step is the Adopt an Integrated Approach. CBT projects that focus on tourist villages will become more complex as they travel, giving rise to new, more complex types of businesses. Therefore, there is a need for encouragement to integrate in sustainable development both regionally, nationally and internationally. CBT can be integrated with other economic sectors in rural areas which can improve mutually supportive relationships and can reduce financial leakage outside the local area. This can be coordinated if the batik craftsmen increase that the urge to set up a wax processing factory in Tampo Village to make batik deserves special attention. In addition to horizontal integration within communities, the success of local ecotourism initiatives may depend on vertical integration with national level initiatives to support and promote responsible tourism. As well as making links to what may already be there, efforts should be made to influence national policies that support rural tourism, including coordination between ministries and tourism and environmental policies.

The seventh step is Plan and Design Quality Products. At this stage the leaders and all local communities who play a role in developing tourism villages formulate potential tourism programs and products comprehensively covering all fields that support tourism sustainability.

The eighth step is Identify Market Demand and Develop Marketing Strategy. Seeing market demand for tourism is something that needs to be considered so that marketing strategies can be made according to market demand. Promotion efforts through social media such as using Instagram, Facebook, Twitter, Tik Tok, and Blogs need to be continuously developed. In addition, you can participate in exhibitions held by the Ministry of Tourism and Creative Economy.

The ninth step is Implement and Monitor Performance. At this stage, it is the stage of implementing the plan in the previous stage, besides implementation, monitoring is needed to evaluate the implementation of tourism village development. The benefits of evaluating 
the CBT project are used to create better strategies for the sustainability of communitybased tourism villages.

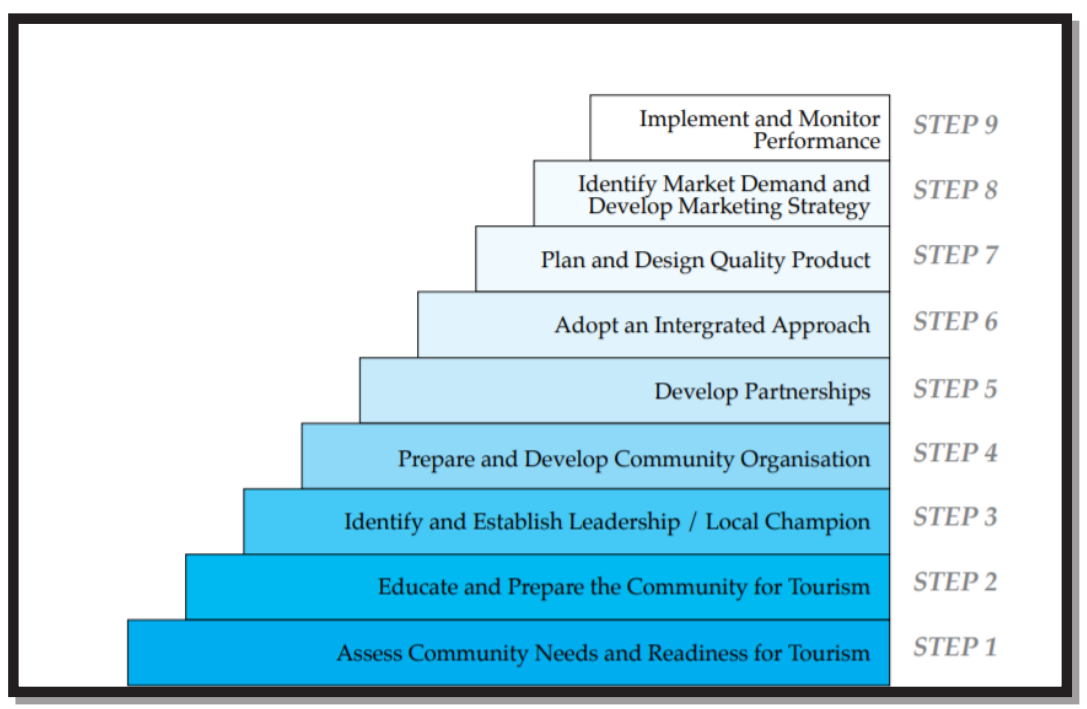

Fig. 3. Step to Develop CBT Sustain

\section{Conlusion}

Tampo batik tourism village is a tourist village that has a distinctive feature of developing the potential for batik typical of Banyuwangi Regency, but the number of craftsmen does not have any influence on the number of visitors. This happened because of the lack of conceptualized tourism village model based on the local wisdom of Batik in the village of Tampo. Some of the key elements or criteria that have an important influence on the development of a tourism village are the capacity of human resources, institutions, facilities and infrastructure, and marketing. These four key elements are indicators to assess the condition of tourism in Tampo Village. The indicators in each tourist village are different because each village has certain characteristics. Each indicator has sub-criteria that are adjusted to the potential of the existing area. Tampo Village itself has characteristics and uniqueness in the field of culture and tradition, so the indicators and sub-criteria are made according to the potential associated with the batik industry cluster.

The development of the batik industry in Tampo aims to preserve cultural wealth and develop the potential that exists in Tampo Village. The potential for batik is one of the means to increase the economic growth of the village of Tampo. Tampo village is the target of the batik industry development because it has a larger number of batik artisans compared to other regions. In addition to the number of batik craftsmen who reach $17 \mathrm{craftsmen}$, this region also has 17 batik industrial centers. The products of the village of Tampo are printed and written batik with the main commodity being written batik. The process of developing the batik industry in Tampo Village is supported by the government, cultural observers, batik craftsmen, and the community. Forms of government support are: 1) designation of Tampo Village as a batik village, 2) infrastructure improvements, and 3) marketing and promotion through the canting sewu festival which is held annually. Good coordination between the community and the government has resulted in the development of industry as a regional potential running optimally. Other benefits felt by the community with this 
development are that it can reduce the unemployment rate, expand employment opportunities, and increase family income.

\section{References}

1. C. C. Lee and C. P. Chang, Tour Manager (2008)

2. E. s. O. Bae, M. Chang, E. S. Park, and D. C. Kim, Journal of Open Innovation: Technology, Market, and Complexity (2017)

3. M. Castro-Nuño, J. A. Molina-Toucedo, and M. P. Pablo-Romero, Journal of Travel Research (2013)

4. Kementerian Pariwisata dan Ekonomi Kreatif Republik Indonesia, "Data kunjungan wisatawan mancanegara bulanan tahun 2019," kemenparekraf.go.id (2020)

5. W. Ning, The Political Nature of Cultural Heritage and Tourism: Critical Essays, 3 (2017)

6. R. Nunkoo and K. K. F. So, Journal of Travel Research (2016)

7. T. Kiper, Advances in Landscape Architecture (2013)

8. N. Ismail, T. Masron, and A. Ahmad, SHS Web Conf. (2014)

9. B. P. Statistik, "Statistik Obyek Daya Tarik Wisata 2018”, 2529, https://www.bps.go.id/

10. B. K. Banyuwangi, "Badan pusat statistik kabupaten banyuwangi”, (2017)

A. Nikolova and L. Hens, Environmental Management in Practice:Compartments, Stressors and Sectors (2013)

11. T. M. Cheng, H. C. Wu, and L. M. Huang, Journal of Sustainable Tourism (2013)

12. D. Krešić and D. Prebežac, Tourism: An International Interdisciplinary Journal, 4 (2011)

13. D. Kim and R. R. Perdue, Journal of Travel \& Tourism Marketing, 225 (2011)

14. Moeljadi, S. Pramono, and S. O. Yuniarsa, International Journal of Management and Business Research (2018)

15. M. S. Amerta, International Journal of Social Science and Humanity, 3, 97( 2017)

16. C.-H. Chin, F.-Y. Law, M.-C. Lo, T. Ramayah, Glob. Bus. Manag. Res., 2, 115 (2018), https://search.proquest.com/

17. R. Federation, Eur. J. Econ. Stud., 2, 309 (2016)

A. Yanes, S. Zielinski, M. D. Cano, and S. Il Kim, Sustain., 9, 1 (2019)

18. T. H. Lee and F. H. Jan, Tour Manager, 70, 368 (2019)

19. The ASEAN Secretariat, Asean Community Based (2016)

20. K. D. Regmi et al., Handbook on Community Based Tourism "How to Develop and Sustain CBT", December, 5, (2015) 